\title{
МЕЖДУ КОНСТАНТИНОПОЛЕМ И КОНСТАНТИНОПОЛЕМ. ИЗ ИСТОРИИ СТОЛИЧНОГО СТАТУСА НИКЕИ В ХІІІ В.
}

\author{
MirostaW J. LesZKA
}

ABSTRACT. Mirosław J. Leszka, Между Константинополем и Константинополем. Из истории столичного cтатуса Никеи в ХІІІ веке. (Between Constantinople and Constantinople: Nicaea as a capital and its role in 13th century).

Balcanica Posnaniensia. Acta et studia, XIX, Poznań 2012, Wydawnictwo Instytutu Historii UAM, pp. 39-49, ISBN 978-83-63-047-17-7, ISSN 0239-4278. Russian text with a summary in Polish and in English.

Mirosław J. Leszka, Uniwersytet Łódzki, Instytut Historii, Katedra Historii Bizancjum, ul. Aleksandra Kamińskiego 27a, 90-219 Łódź, Polska - Poland.

С захватом Константинополя участниками Четвертого крестового похода в апреле 1204 г. начинается продолжающийся больше полвека период, в котором этот город не исполнял роль столицы византийской империи. Столичного статуса в это время добилась же малоазиатская Никея ${ }^{2}$. Она стала центром государства, которого правители считали себя наследниками константинопольских василевсов. От имени своей столицы эта страна получила название Никейской империи.

Никея, вероятно, с самого начала существования в качестве столичного города воспринималась как временная столица, потому что центральным пунктом политической системы тамошних правителей было возвращение над Босфор, в Константинополь, единственный город, который считался настоящей столи-

1 Этот текст - отредактированная и несколько расширенная версия польскоязычной статьи, которая первоначально была опубликована в научном журнале: „Piotrkowskie Zeszyty Historyczne” $12.2,2011$, c. $211-220$.

2 Никея не была - как известно - единственным городом, пытающимся занять место Константинополя. На эту роль претендовали также Трапезунд и Фессалоники, столицы греческих государств, соперничающих с Никейской империей. Подробнее по теме Трапезундской империи и Фессалоникского королевства см.: С. Карпов, История трапезундской империи, Санкт-Петербург 2007; A. Stavridou-Zafraka, The Empire of Thessaloniki (1224-1242). Political Ideology and Reality, Byzantiaka 19, 1999, c. 213-222; F. Bredenkamp, The Byzantine Empire of Thessaloniki, Thessalonike 1993. 
цей византийской империи ${ }^{3}$. Однако кажется, что временность столичного статуса Никеи парадоксально дает нам великолепную возможность определить факторы, из которых в сознании византийцев складывалось понятие столичности. Именно эти элементы надо было осуществлять правителям Никейской империи, чтобы их резиденция - хотя бы за короткое время - воспринималась как достойная заместительница находящегося в руках крестоносцев Константинополя. Прежде чем приступлю к анализу действий никейских правителей, предприняmblx с целью присвоения своей резиденции столичного статуса, я хотел бы коротко объяснить, на чем основывалась столичность Константинополя.

Константинополь. Его столичный статус складывался постепенно и эволюционно. Можно полагать, что этот процесс начался вместе с основанием города в 330 г. и продолжался несколько столетий. Едва ли будет ошибочным утверждение, что в основном закончился он в VI в. ${ }^{4}$ K сложившимся в этом периоде основным чертам, определяющим уникальный характер Константинополя, именно его столичность, можно причислить прежде всего три. Во-первых, столицей Византии был всегда только один город и независимо от того, где в какоето, определенное время пребывал император, сохранял он свой столичный статус. Был постоянной резиденцией верховного правителя, его дворцового окружения и высочайших государственных учреждений. Обладание ним легализировало верховную власть. Императорская прокламация, состоявшаяся вне Константинополя, всегда должна быть повторена в черте столичного города, потому что только в пределах столицы мог совершиться вполне законный обряд коронации. Во-вторых, Царьград был также местом постоянного пребывания патриарха, неединственного в Византии (ко времени захвата Сирии, Палестины и Египта арабами), но безусловно главнейшего. В ведении константинопольского патриарха находилось право венчания императора. Столица являлась также религиозным центром государства. Местом, где находился Постоянный Собор (Синод эндемуса), хранились святые реликвии, процветала монастырская жизнь.

\footnotetext{
3 Как считает Майкл Ангольд, автором византийской «идеологии изгнания» (ideology of exile) был Никита Хониат, который в своих сочинениях (например: Logos XIII, с. 128. 24-27; XIV, c. 147, 1-7; изд.: Nicetae Choniatae Orationes et epistulae, ed. J.-L. van Dieten, Berolini et Novi Eboraci 1972) недвусмысленно высказывался о необходимости возвращения в Константинополь. Феодор Ласкарь - как Моисей или Зоровавель - должен возвратиться в Новый Иерусалим, Константинополь, столицу византийского государства. Подробнее по этой теме см.: M. Angold, Byzantine Government in Exile. Government and Society under the Laskarids of Nicaea (1204-1261), Oxford 1975, c. 13-14; idem, Church and Society in Byzantium under the Comneni, 1081-1261, Cambridge 2000, c. 518; П.И. Жаворонков, Западные и восточные реалии в социално-политической и духовной жизни Никейской империи, [в:] Византия между Западом и Востоком. Опыт исторической характеристики, ed. Г.Г. Литаврин, Санкт-Петербург 1999, с. 208.

4 Подробнее по теме развития столичного статуса Константинополя см.: M.B. Leszka, M.J. Leszka, Ewolucja statusu miasta. Idea Konstantynopola-Nowego Rzymu и Zarys dziejów Konstantynopola $w$ latach 337-602, [в:] Konstantynopol - Nowy Rzym. Miasto i ludzie $w$ okresie wczesnobizantyńskim, ed. M.J. Leszka, T. Wolińska, Warszawa 2011, c. 38-101 (там очередные библиографические данные).
} 
И третья предпосылка - со времени правления Константина Великого существовала тесная идеологическая связь между Константинополем и Римом. По замыслу своего основателя Царьград был не столько Новым или Вторым Римом, сколько Римом sensu stricto - носителем государственных традиций древнеримской империи. По мере того, как развивался Константинополь, Рим постепенно терял свое значение. В конце концов, город над Босфором стал действительной столицей римского государства.

Конечно, можно обнаружить ряд других факторов, определяющих уникальный характер столичного города в византийской системе. Среди них я хотел бы подчеркнуть еще один - чрезвычайную заботу императоров о своей столице, в области широко понятой эстетики (строительство прекрасных зданий и памятников) и практики повседневной жизни (защита города, водоснабжение, продовольствие, сохранение общественного порядка).

Никея. В апреле 1204 г. Константинополь был захвачен участниками четвертого крестового похода. Когда Алексей V бежал из города, часть константинопольской знати попыталась провозгласить императором его наследника. Из двух кандидатов - Константина Дуки и Константина Ласкаря - избран второй. Некоторые исследователи считают, что Константин Ласкарь был коронован тогдашним константинопольским патриархом Иоанном Каматиром в св. Софии. Не имея возможности открыто выступить против латинянам, он покинул Константинополь и отправился в Никею, находящуюся недалеко от столицы, в малоазиатской провинции Вифинии. Кажется, что жители Никеи приняли Константина Ласкаря хорошо и признали его императором 5 . Показательно, что не пожелали впустить в город его брата, Феодора Ласкаря (покинувшего Константинополь перед его захватом участниками Четвертого крестового похода) ${ }^{6}$, который, не получая от них

\footnotetext{
${ }^{5}$ B. Sinogowitz, Über das byzantinische Kaisertum nach dem Vierten Kreuzzüge (1204-1205), „Byzantinische Zeitschrift” 45, 1952, с. 345-356; П.И. Жаворонков, У истоков образования Никейской империи (оценка деятельности Константина XI Ласкариса), „Византийский Временник” 38, 1977, c. 30-31; Георгий Акрополит, История, прев., коммент., прилож., П.И. Жаворонков, Санкт - Петербург 2005, с. 7 (далее: П.И. Жаворонков - Георгий Акрополит); A.G.C. Savvides, Constantine XI Laskaris, uncrowned and ephemeral "Basileus of the Rhomaioi" after the Fall Constantinople to the Fourth Crusade, „Byzantiaka” 7, 1987, c. 141-174; см. также: G. Ostrogorski, Dzieje Bizancjum, ed. H. Evert-Kappesowa, Warszawa 1968, c. 341-342; C. Foss, J. Tulchin, Nicaea: a Byzantine Capital and Its Praises. With the Speeches of Theodore Laskaris, In Praise of the Great City of Nicaea, Theodore Metochites, Nicene Oration, Brookline 1996, с. 57; C. Foss, Emperors named Constantine, „Revue numismatique” 2005, vol. 6, № 161, c. 90-99. Знаю, что большинство исследователей оставляет в стороне или только лаконически упоминает о предположительном участии Константина Ласкаря в основании Никейской империи. Однако кажется, что приведенные в литературе предмета аргументы, подтверждающие тезис о его активной роли в событиях 1204-1205 г., являются по крайней мере достоверными.

6 Феодор покинул столицу спустя некоторое время после того, как Алексей III, его тесть был лишен верховной власти. N. Oikonomidès, La décomposition de l'empire byzantine à la veille de 1204 et les origines de l'empire de Nicée: A propos de la „Partitio Romanie”, [в:] XVE Congrès International d'Etudes byzantines. Rapport et co-rapports, Athènes 1976, с. 22-28; George Akropolites, The History, transl., introd., comment. R. Macrides, Oxford 2007, с. 82 (далее: R. Macrides); J. Bonarek, Separatyzm bizantyński w dobie IV krucjaty a działalność Teodora Laskarysa, „Piotrkowskie Zeszyty Historyczne” 9, 2008, c. 34;
} 
никакой помощи, был принужден уйти в район Прусы ${ }^{7}$. Очень трудно ответить на вопрос, почему Константин Ласкарь решил поселиться в Никее. Можно полагать, что в основе его решения лежал тот факт, что она была, вместе с находящейся в руках крестоносцев Никомедией, одним из важнейших городов поблизости от Константинополя. Следовательно, она могла исполнять роль центра, из которого было удобно отправляться в походы против латинян и - одновременно - контролировать отношения с турками-сельджуками. Укрепления Никеи могли оборонять город от возможного захватчика ${ }^{8}$ - латинян. Существенным является также тот факт, что Никея гордилась своей блестящей историей. В пределах города прочим двукратно состоялся Вселенский Собор $(325,787)^{9}$. Кроме того, она была важным административным центром. Но не Константина Ласкаря надо считать настоящим основателем столичного статуса Никеи. Им является его брат Феодор Ласкарь ${ }^{10}$, зять императора Алексея III Ангела, которому удалось подчинить себе города южной Вифинии, Мисии и района Смирны ${ }^{11}$. Константин же пытался установить мирные отношения с турками-сельджуками и воспротивиться экспансии крестоносцев ${ }^{12}$. В сражении с латинянами ему не повезло 19 марта 1205 г. был разбит при Адрамитии ${ }^{13}$. Это поражение очень сильно повлияло на его политическую ситуацию - он не пользовался больше поддержкой греческого населения и не имел авторитета ${ }^{14} .14$ апреля 1205 г. и латиняне были принуждены отступить из Малой Азии в результате разгрома в битве с болгарами под Адрианополем ${ }^{15}$. Вследствие изменившихся обстоятельств укрепилось положение Феодора Ласкаря - он подчинил себе оставленные латинянами области ${ }^{16}$ и в скором времени был провозглашен императором. Избрание Феодора

I. Giarenis, He synkrotesi kai he hedraiosi tes autokratorias tes Nikaias. Ho autokratoras Theodoros A Komnenos Laskaris, Athena 2008, с. 45-46; другая версия событий: П.И. Жаворонков, У истоков ..., c. 31; П.И. Жаворонков - Георгий Акрополит, с. 164-165; A.G.C. Savvides, op. cit., c. 161.

7 Георгий Акрополит, 6 (Georgii Acropolitae Opera, t. I-II, rec. A. Heisenberg, cor. P. Wirth, Stuttgart 1979); по теме недружелюбной установки жителей Никеи по отношению к Феодору см.: N. Oikonomidès, op. cit., c. 27; J.-C. Cheynet, Pouvoir et contestations à Byzance, Paris 1996, c. 463, 469; I.L. Booth, Theodore Laskaris and Paphlagonia, 1204-1214: towards a chronology description, „Archeion Pontou” 2003/2004, с. 162; ср. П.И. Жаворонков, У истоков .., с. 31.

8 O состоянии укреплений Никеи перед Четвертым крестовым походом - C. Foss, J. Tulchin, op. cit., c. 93.

${ }^{9}$ A.G.C. Savvides, Byzantium in the Near East: Its Relations with the Seljuk Sultanate of Rum in Asia Minor, the Armenians of Cilicia and the Mongols A.D. c. 1192-1237, Thessaloniki 1981, c. 53.

10 П.И. Жаворонков, У истоков ..., с. 37.

11 Ibidem, c. 32.

12 Ibidem, c. 32.

13 Ibidem, c. 34-35; см. также: Z. Pentek, Cesarstwo Eacińskie. Kolonialne państwo krzyżowców czy Neobizancjum, Poznań 2004, c. 91.

14 П.И. Жаворонков, У истоков ..., с. 35; A.G.C. Savvides, Constantine XI..., c. 163.

15 По теме битвы под Адрианополем и ее последствий см.: А. Данчева-Василева, България и Латинская империя (1204-1261), София 1985, с. 60-73; В. Гюзелев, Калоянова България и Латинская империя (1204-1207), [в:] Одринката битка от 1205 година, ed. idem, София 2005, c. 13-26; Й. Андреев, Победа на ичар Калоян при Одрин -14април 1205, [в:] ibidem, с. 43-52.

16 П.И. Жаворонков, У истоков ..., с. 36. 
светской и церковной знатью состоялось именно в Никее. Это событие датируется 1205 г. $^{17}$

Источники содержат информацию о том, что Никея с самого начала была центром основанного Феодором государства. Такое значение придает ей в своем сочинении с 1206 г. Никита Хониат ${ }^{18}$. Жоффруа де Виллардуэн упоминает ее в качестве столицы Феодора, когда реконструирует ход событий с 1206 г. ${ }^{19}$ Свидетельством того, что Никея уже в этот период была резиденцией Феодора и местом расположения его войск, является факт, что осенью 1206 г. именно из нее император отправлялся в поход против Давида Пафлагонского, представляющего собой, со времени заключения союзного договора с латинянами, немалую угрозу ${ }^{20}$. Несколько месяцев позже, в апреле 1207 г., Феодор предпринял из Никеи другой поход - на находящуюся в руках латинян Никомедию ${ }^{21}$. Известно, что в это время император занимался также градостроительством. Никифор Блеммид в своем сочинении упоминает о постройке императорского дворца ${ }^{22}$. Надпись, обнаруженная на юго-восточной башни никейских крепостных стен, свидетельствует о том, что их строили в 1208 г. $^{23}$ Город, являющийся важнейшим центром борьбы с латинянами, стал местом, в котором поселялось большое количество беженцев, светских и духовных лиц (например, Никита Хониат или Максим и Герман, будущие патриархи) $)^{24}$.

В укреплении столичного статуса Никеи в основанном Феодором государстве сыграло чрезвычайно важную роль перенесение резиденции константинопольского патриарха. Иоанн Каматир после захвата византийской столицы кре-

17 П.И. Жаворонков (У истоков ..., с. 36) считает, что Константин Ласкарь спустя недолгое время после битвы при Адрамити попал в плен к Феодору, который принудил его отказаться от императорского сана. В этой обстановке Феодор мог попытаться обеспечить себе возведение на императорский престол. О датировке императорской прокламации Феодора Ласкаря: П.И. Жаворонков, Избрание и коронация никейских императоров, „Византийский Временик” 49 , 1988, c. 55; R. Macrides, c. 82-84.

18 Никита Хониат, Logos XIV, c. 139.6-12.

19 Geoffroy de Villehardouin, par. 455 (Villehardouin, La conquête de Constantinople, par. 455, ed., trad. E. Faral, t. I-II, Paris 1974; польский перевод: Geoffroy de Villehardouin, Zdobycie Konstantynopola, ed. Z. Pentek, Poznań 2003, c. 173).

${ }^{20}$ Никита Хониат, с. 640 (изд.: Nicaetae Choniatae Historia, ed. J.-L. van Dieten, Berolini et Novi Eboraci 1975); об этом походе см.: Р.М. Шукуров, Великие Комнинь и Восток (1204-1461), Санкт Петербург 2001, с. 80; С. Карпов, op. cit., с. 100.

21 Villehardouin, par. 481 (Жоффруа де Виллардуэн называет город „Великой Никеей”). 1984.

22 Nicephori Blemmydae Autobiographia sive curriculum vitae, I, 12, ed. J.A. Munitiz, Turnhout

23 К сожалению, надпись не сохранилась до наших дней. Единственным источником информации на эту тему является сочинение Джона Ковела, капеллана английского посла в Стамбуле в периоде 1669-1677. J. Raby, A Seventeenth-Century Description of Iznik-Nicaea, „Istanbuler Mitteilungen” 26, 1976, c. 157, 180-181; C. Foss, D. Winfield, Byzantine Fortifications: an Introduction, Pretoria 1986, c. $81,85-86,102-103$; C. Foss, J. Tulchin, op. cit., c. 93-94.

${ }^{24}$ C. Foss, J. Tulchin, op. cit., c. 58-59. Стоит отметить, что следующая волна беженцев, прежде всего священников и монахов, явилась в Никею после заключения Феодором I Ласкарем договора с латинянами в 1212 г. (ibidem, с. 61). 
стоносцами, покинул ее и отправился в Дидимотеихон, где умер в мае 1206 г. Попытки пригласить его в Никею оказались безуспешными. Представители церковной знати, находившиеся в Никее, и Феодор Ласкарь прекрасно понимали необходимость избрания нового патриарха. Для императора присутствие патриарха в городе было чрезвычайно важно, потому что только он имел право совершать обряд коронации. Прошедший в Никее синод, вероятно в марте 1208 г. назначил первым константинопольским патриархом, постоянно пребывающим в Никее, Михаила Авториана ${ }^{25}$. С тех пор город был столицей государства, претендующего на имя наследника византийской империи и - в то же время - резиденцией константинопольского патриарха. В скором времени Михаил Авториан венчал Феодора императором ${ }^{26}$. Все следующие коронации, до отвоевания Константинополя, совершались в Никее ${ }^{27}$.

Восстановленный в Никее константинопольский патриархат действовал в рамках многовековой традиции. Организовано синоды, например, в 1234 г. по вопросу унии с Римской церковью. Можно также полагать, что в Никее - как и в Константинополе - работал Постоянный Собор (Синод эндемуса $)^{28}$. Не была построена патриаршая церковь, но эту роль стал исполнять храм Богородицы в монастыре св. Иакинфа ${ }^{29}$. Первоначально единственным источником дохода патриарха были имения никейского метрополита, потом постепенно расширялись благодаря многочисленным дарам и вкладам правителей ${ }^{30}$.

Никея стала также местом, в котором совершались различные официальные церемонии, связанные с императорской семьей, в том числе - браки и похороны. В 1241 г. жители Никеи имели великолепную возможность наблюдать обряд венчания Иоанна III Дуки Ватаца и Констанции, дочери Фридриха II Штауфена ${ }^{31}$. В Никее похоронили Феодора Ласкаря, его жену Анну и тестя - Алексея III Ангела $^{32}$. Роль царской усыпальницы частично исполняла упомянута уже церковь Богородицы в монастыре св. Иакинфа. Однако, не все никейские императоры были захоронены в патриаршей церкви или в Никее, например гробницы

25 Об избрании Михаила Авториана см.: M. Angold, op. cit., с. 49; о его деятельности в качестве константинопольского патриарха см.: I. Giarenis, op. cit., c. 245-254.

${ }^{26}$ На тему императорской коронации Феодора I Ласкаря см.: П.И. Жаворонков, Избрание..., c. 56-57. Попытки датировать это событие 1207 г. (например, P. Gounaridis, He chronologia tes anagoreuses kai tes stepses tou Theodorou A tou Laskareos, „Symmeikta” 6, 1985, с. 59-71) являются неоправданными. R. Macrides, c. 83, прим. 517; I. Giarenis, op. cit., c. 48.

27 C. Foss, J. Tulchin, op. cit., c. 75.

28 Ibidem, c. 68.

29 На тему монастыря св. Иакинфа см.: R. Janin, Les Églises et les monastères des grands centres byzantins, Paris 1975, с. 121-124.

30 Подробнее по теме владений патриархата см.: C. Foss, J. Tulchin, op. cit., c. 67, 76.

31 Ibidem, c. 65.

32 Георгий Акрополит, 18. 
Иоанна III Дуки Ватаца и Феодора II Ласкаря находятся в монастыре Сосандра в районе Магнесии у Сипила (Magnesia ad Sipylum) ${ }^{33}$.

Правители заботились о городе. Строили в нем разные здания (церковные, военные, общественные) для общего пользования жителей. Делал так уже Феодор Ласкарь (укрепление крепостных стен города) $)^{34}$, но самым действенным строителем был Иоанн III Дука Ватац. Именно ему никейцы могли быть признательными за расширение укреплений, обороняющих город от возможного захватчика. По его заказу построено внешние стены, перед которыми находился ров, внутренние же стены повышены о 2,5 м ${ }^{35}$. К. Фосс, исследователь истории Никеи, считает, что неслучайно после расширения никейские крепостные стены напоминали укрепления Константинополя ${ }^{36}$. Употребление при строительстве яркого раствора привело к тому, что стены были видными издалека и блестели на солнце как снег. Средневековые свидетели, подчеркивая красоту города, упоминают не только прекрасные здания (многочисленные церкви ${ }^{37}$, расположенный выше города императорский дворец, крепостные стены), но также обширные зеленые пространства (луга, сады, поля). Никого не удивляет, что красота и уникальность Никеи, так как Константинополя, стали темой литературных произведений ${ }^{38}$. Среди них надо упомянуть прежде всего енкомий Феодора II Ласкаря, написанный в последные годы правления его отца, Иоанна Ватаца. Феодор восхваляет в нем красоту Никеи, а кроме того уверяет читателя в своем уважении к жителям города, который характеризует с риторической эм-

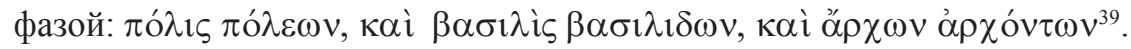

Никейские правители стремились к тому, чтобы их столица стала научным и культурным центром. Известно, что в Никейской империи существовала, заимствованная из Константинополя, должность консула философов, ответственного

33 R. Macrides, c. 274; 335-336; E. Mitsiou, The Monastery of Sosandra: a contribution to its history, dedication and localisation, "Bulgaria Mediaevalis" 2, 2011, с. 665-666. Монастырь Сосандра был основан Иоанном III Ватацом в качестве его усыпальницы. Строительные работы начались после 1225 г. и завершились до 1241 г. Монастырь находился сравнительно недалеко от Магнесии у Супила, но его точная локализация неизвестна. Поблизости от него находился также монастырь Theotokos tou Kouzenas, основанный Ириной, женой Иоанна III Ватаца.

34 C. Foss, J. Tulchin, op. cit., c. 93.

35 Подробнее по теме расширения крепостных стен Никеи во время правления Иоанна III Ватаца см.: C. Foss, J. Tulchin, op. cit., с. 94-95; см. также: A. Bryer, Nicaea, a Byzantine City, „History Today" 21.1, 1971, c. 30.

36 C. Foss, J. Tulchin, op. cit., c. 95.

37 На тему сакральных зданий в Никее см.: R. Janin, op. cit., c. 119sq; C. Foss, J. Tulchin, op. cit., c. 96-111. Безусловно, важнейшими среди них были: церковь Богородицы в монастыре св. Иакинфа, храм Софии - Премудрости Божией и иерковь св. Трифона.

38 A.G.C. Savvides, Byzantium in the Near East..., c. 54. Стоит отметить прежде всего сочинения Никифора Блеммида (восхваляющего солидность крепостных стен города и добродетели его жителей) и посвященное Никеи слово похвальное Феодора Метохита (Nikaeus).

39 Theodorou Douka tou Laskari enkomion eis ten megalopolin Nikaian, 1, [в:] C. Foss, J. Tulchin, op. cit., c. 132. 
за образование и просвещение ${ }^{40}$. В Никее нашли прибежище самые выдающиеся ученые эпохи, н.п. Никита Хониат, Никифор Блеммид, Николай Месарит. Феодор II Ласкарь основал дворцовую школу при церкви св. Трифона (специально расширенной и приспособленной). Император, писатель и ученый, лично заботился и о работавших в ее стенах учителях, и о их студентах ${ }^{41}$. Известно, что первыми преподавателями в этой школе были Михаил Сеннахерим ${ }^{42}$ и Андроник Франгопул ${ }^{43}$.

В отличие от своих константинопольских предшественников никейские императоры проводили много времени вне своей столицы. Главнейшими резиденциями являлись: Нимфайон (где они обычно пребывали зимой) ${ }^{44}$ и Магнесия у Сипила, в которой находился императорский монетный двор и хранилась казна $^{45}$. Однако, учитывая значение этих городов, прежде всего Нимфайон, надо подчеркнуть, что именно Никея - независимо от места пребывания императора - была главнейшим городом в государстве ${ }^{46}$.

Никеа исполняла роль столицы византийской империи „в изгнании” на протяжении почти 60 лет. Несмотря на свой временный статус, она приобрела большинство черт, составляющих византийскую модель столичного города (резиденция императора и патриарха, место коронации правителей, научный и культурный центр, „презентабельный” город, пользующийся особой заботой правителей). Ее столичность имела один немаловажный недостаток - Никея не была Константинополем. Никита Хониат пишет, что она воспринималась как Вавилон византийцев ${ }^{47}$, из которого - после расплаты за свои грехи - они возвратятся в Константинополь, свою „обетованную землю”48. И это произошло летом 1261 г., когда Константинополь был отвоеван Михаилом VIII Палеологом.

\section{Перевела с польского Zofia Brzozowska}

40 Так считает Майкл Ангольд (M. Angold, op. cit., c. 179); см. также: C. Foss, J. Tulchin, op. cit., c. 67. Известно, что этот пост занимал Феодор Иреник, который в 1214 г. получил сан патриарха. Этот факт свидетельствует о том, что должность консула философов появилась в Никее недолго спустя после того, как она стала столицей государства Феодора Ласкаря.

41 M. Angold, op. cit., c. 179-180; C. Foss, J. Tulchin, op. cit., c. 67-70.

42 Михаил Сеннахерим возглавил кафедру риторики, а Андроник Франгопул - граматики. Лучше изученными являются карьера и достижения Сеннахерима. M. Angold, op. cit., с. 180; N. Wilson, Scholars of Byzantium, Baltimore 1983, c. 219; C. Foss, J. Tulchin, op. cit., c. 69-70.

43 П.И. Жаворонков, Западные..., с. 211.

44 Георгий Акрополит, 84.

45 M. Salamon, Mennictwo bizantyńskie, Kraków 1987, c. 282; C. Foss, J. Tulchin, op. cit., c. $61,65$. Монетный двор был перенесен в Магнесию из Никеи.

46 На тему значения Нимфайон см.: R. Macrides, c. 87-88; П.И. Жаворонков - Георгий Акрополит, с. 191. Здесь находился императорский дворец.

47 Choniatou Mihael Akominatou, ta sodzomena, ed. S. Lambros, t. I, Athens 1879, c. 354-355; см. также прим. 2 в этой статьи.

48 M. Angold, A Byzantine government..., c. 29; idem, Czwarta krucjata, transl. B. Spieralska, Warszawa 2006, c. 247. 

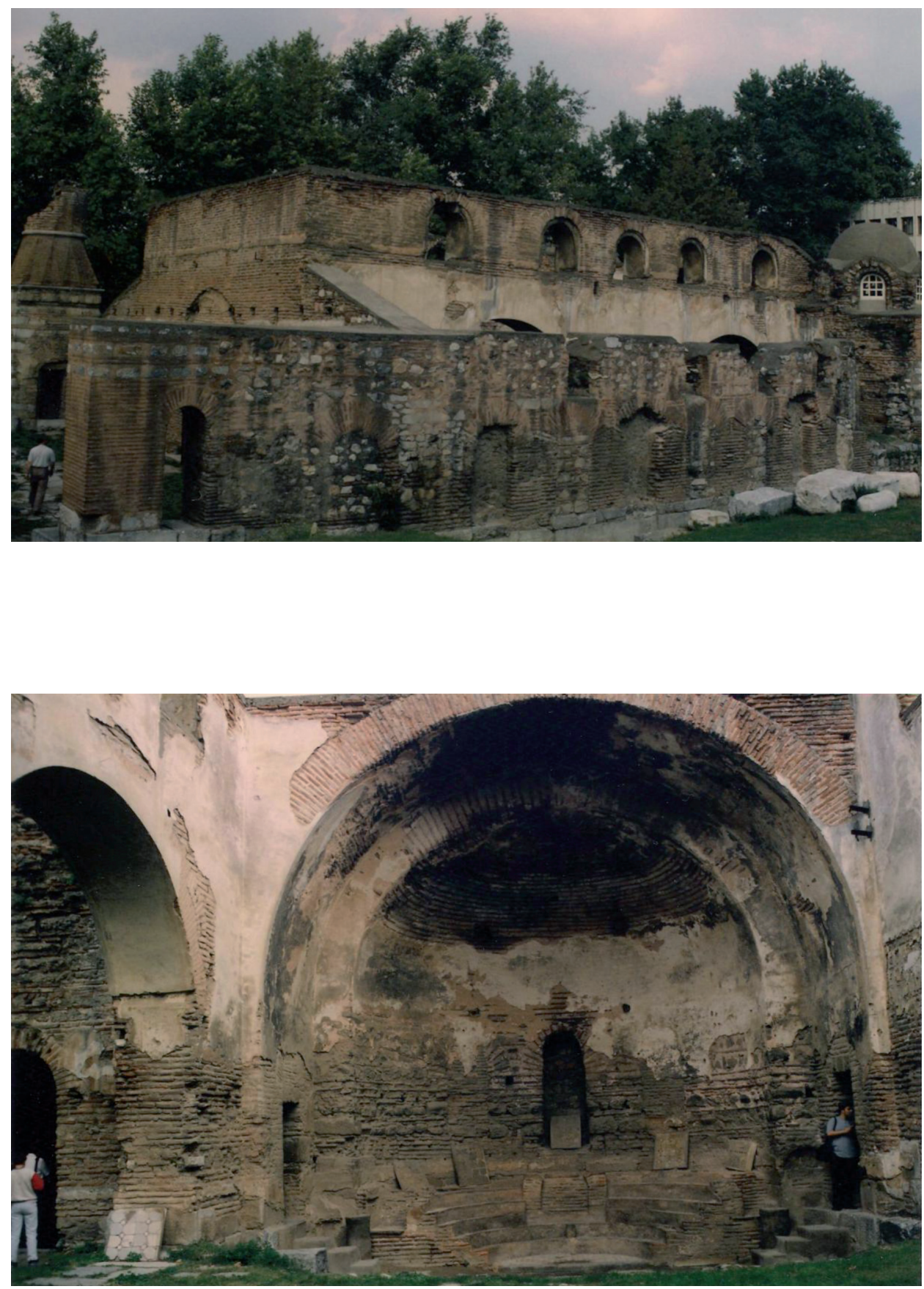

Храм Софии - Премудрости Божией. Вероятно он был основан во время правления Юстиниана I. В 787 г. состоялся в нем VII Вселенский Собор. После землетрясения в 1065 г. был восстановлен и исполнял роль соборной церкви. Фот. М.J. Leszka (1997) 


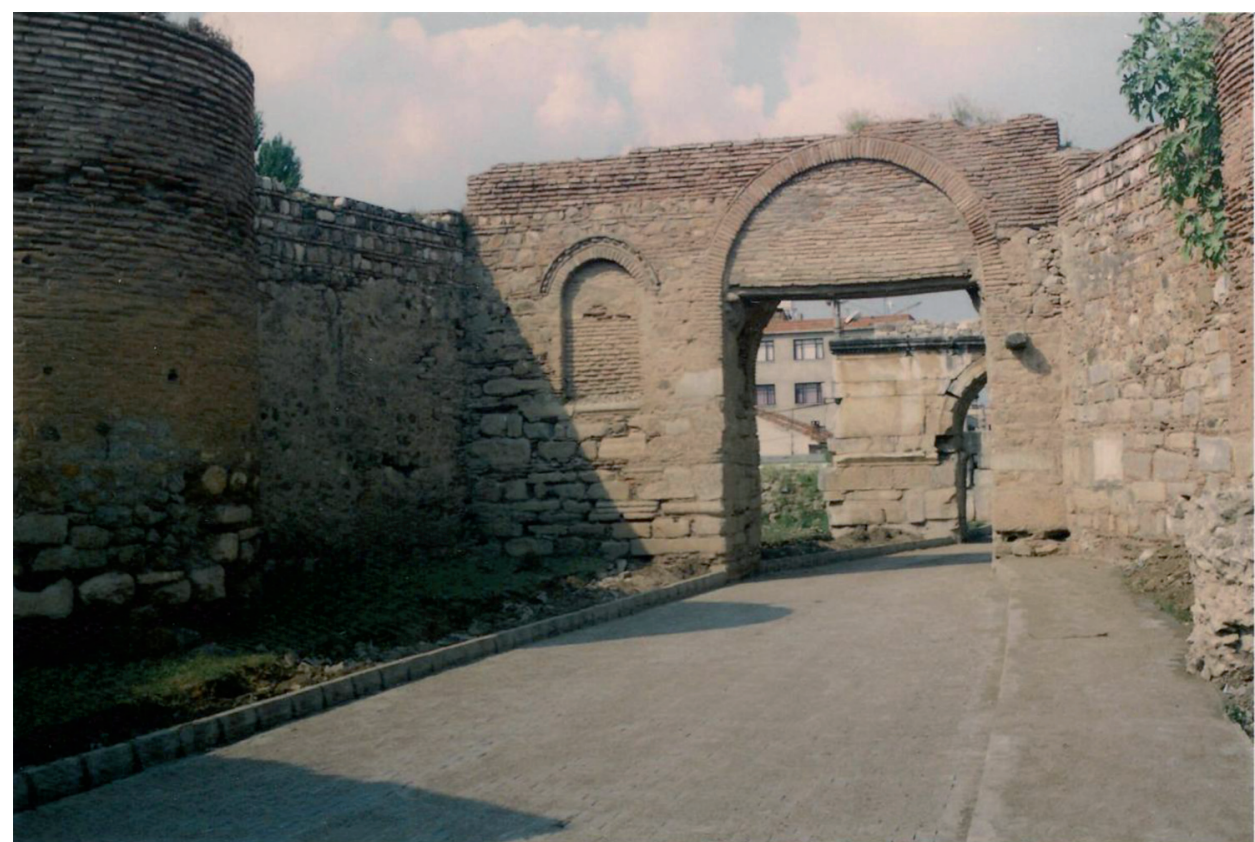

Ворота Лефке - одние из ворот (восточные) в крепостных стенах Никеи. Фот. M.J. Leszka (1997)

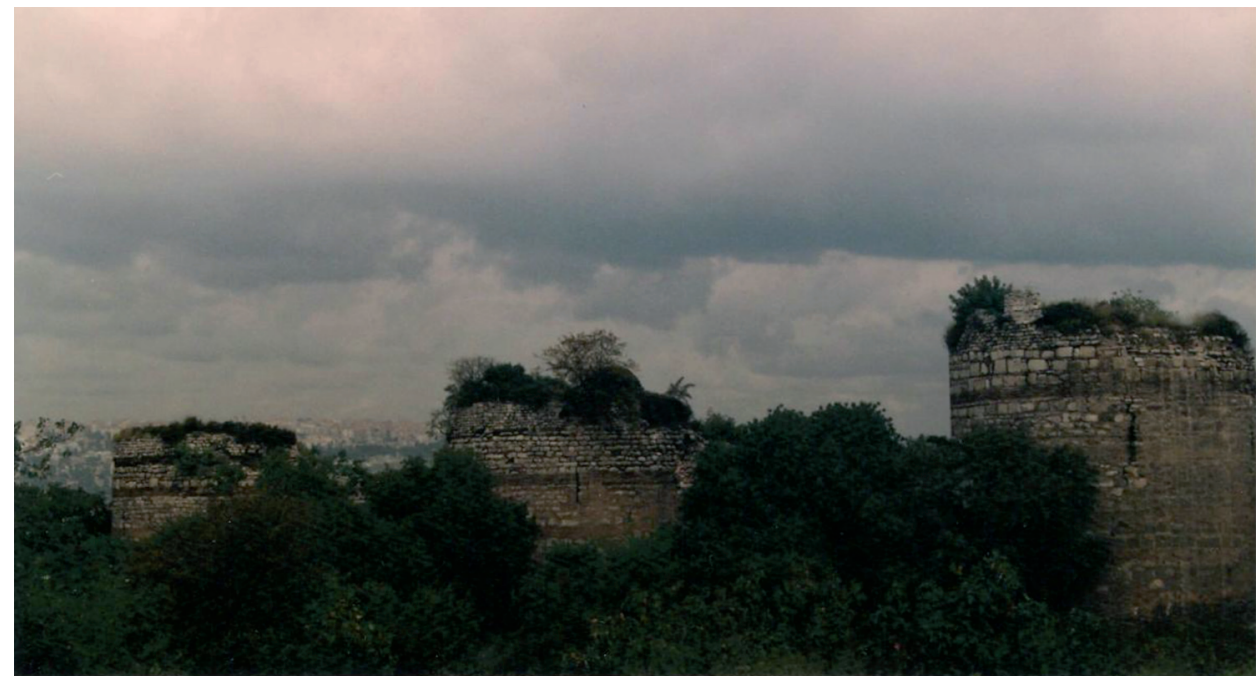

Фрагмент крепостных стен Никеи. Фот. М.J. Leszka (1997) 


\title{
MIĘDZY KONSTANTYNOPOLEM A KONSTANTYNOPOLEM. Z DZIEJÓW STOŁECZNEJ ROLI NICEI W XIII W.
}

\author{
Streszczenie
}

Nicea pełniła rolę stolicy bizantyńskiego państwa niespełna sześćdziesiąt lat. Mimo tymczasowości tej funkcji wypełniała ona większość cech konstytuujących bizantyński model stolicy „typu Konstantynopol” (siedziba cesarza i patriarchy, miejsce cesarskich koronacji, centrum nauki i kultury; „reprezentacyjne” miasto, otoczone szczególną cesarską opieka). Jej stołeczność miała wszakże jeden i to najistotniejszy mankament - Nicea nie była Konstantynopolem. Michał Choniates pisał, że dla Bizantyńczyków Nicea jest Babilonem. Po odpokutowaniu w niej swoich grzechów powrócą do Miasta - swojej „ziemi obiecanej”. Ta przepowiednia spełniła się latem 1261 r., kiedy Konstantynopol znalazł się w rękach Michała VIII Paleologa.

\section{BETWEEN CONSTANTINOPLE AND CONSTANTINOPLE: NICAEA AS A CAPITAL AND ITS ROLE IN 13TH CENTURY}

\author{
Summary
}

Bithynian Nicaea functioned as a capital of the Byzantine state for just under sixty years. Despite that temporariness, the city was able to perform a majority of the roles of the capital 'Constantinopolitan style'. It was a residence of an emperor and a patriarch, a place of the imperial coronations, a centre of culture and science, a stately city under particular imperial protection. It lacked but one, irretrievable feature it was not Constantinople itself. Michael Choniates wrote that Nicaea was a Babylon for the Byzantines and after completing their repentance there they would be allowed to return to the City, their 'promised land'. That prophecy was fulfilled in the summer of 1261, when Constantinople fell into the hands of Michael VIII Palaeologus. 
